\title{
Susceptibility to Spirodiclofen in field populations of Tetranychus urticae (Acari: Tetranychidae) from strawberry plantations in Lima region, Peru
}

\section{Susceptibilidad al Spirodiclofen en poblaciones de campo de Tetranychus urticae (Acari: Tetranychidae) procedentes de plantaciones de fresa de la región Lima, Perú}

\author{
Juan Flores-Bernedo ${ }^{1}$; Javier Vásquez-Castro ${ }^{2 *}$ \\ *Corresponding author: jaque@lamolina.edu.pe
}

https://orcid.org/0000-0003-3407-6938

\begin{abstract}
The use of inhibitors of lipids synthesis is among the available strategies for the control of Tetranychus urticae (Acari: Tetranychidae) in strawberry plantations. The study aimed to monitor the susceptibility to Spirodiclofen in field populations of T. urticae from strawberry plantations in Lima region, Peru. Adult T. urticae were collected from strawberry plantations in districts of Aucallama, Chancay, Huaral, and Santa Rosa de Quives in Lima region, Peru. A population collected from Acalypha wilkesiana in campus of the Universidad Nacional Agraria La Molina (UNALM), where chemical pesticide has never been applied, was used as a susceptible reference line. This reference line was subjected to toxicological bioassays to estimate the $\mathrm{LC}_{50}$ and $\mathrm{LC}_{95}$. Afterward, bioassays were conducted on the population using the $\mathrm{LC}_{50}$ and $\mathrm{LC}_{95}$ estimated for the susceptible reference line. The obtained data was subjected to one-way analysis of variance and mean comparison was done by Tukey test $(\alpha=0.05)$. There were no significant differences between the four populations' $\mathrm{LC}_{50}$ and $\mathrm{LC}_{95}$, with respect to the estimated susceptible reference line. This implies that the four studied populations of T. urticae are susceptible to Spirodiclofen, with no evident resistance problems. Therefore, Spirodiclofen is a useful tool for the control of T. urticae form strawberry plantations in the studied location. The factors that influenced the results are discussed in the present work.
\end{abstract}

Keywords: Resistance, bioassay, diagnostic dose, $L C_{50^{\circ}}, L C_{95}$

\section{Resumen}

El uso de inhibidores de la síntesis de lípidos es una de las estrategias disponibles para el control de Tetranychus urticae (Acari: Tetranychidae) en el cultivo de fresa. El objetivo de la presente investigación fue monitorear la susceptibilidad al Spirodiclofen en poblaciones de T. urticae procedentes de campos de fresa de la región Lima. Se colectaron individuos adultos de T. urticae en campos de fresa de los distritos de Aucallama, Chancay, Huaral y Santa Rosa de Quives en la región Lima. Se utilizó como línea susceptible de referencia una población procedente del campus de la Universidad Nacional Agraria La Molina (UNALM), colectada sobre plantas de Acalypha wilkesiana, en donde nunca se han realizado aplicaciones de plaguicidas químicos. La línea susceptible de referencia fue sometida a bioensayos toxicológicos con el fin de estimar la $\mathrm{CL}_{50}$ y la $\mathrm{CL}_{95}$. Luego, se realizaron los bioensayos con las poblaciones de campo, utilizando la $\mathrm{CL}_{50}$ y $\mathrm{CL}_{95}$ encontrada para la línea susceptible de referencia. Posteriormente, los resultados fueron sometidos al análisis de varianza y comparación de medias por la prueba de Tukey $(\alpha=0.05)$. Las cuatro poblaciones de campo no mostraron diferencias estadísticamente significativas frente a la $\mathrm{CL}_{50} \mathrm{y} \mathrm{CL}_{95}$ estimadas para la línea susceptible de referencia. Esto significa que las cuatro poblaciones estudiadas de T. urticae son susceptibles al Spirodiclofen, no evidenciándose problemas de resistencia. Así, el Spirodiclofen es una herramienta valiosa para el control de T. urticae en el cultivo de fresa en las localidades estudiadas. Los factores que influyeron en los resultados son discutidos en el presente trabajo.

Palabras clave: Resistencia, bioensayo, dosis diagnóstica, $C L_{50^{\circ}} C L_{95^{\circ}}$

\footnotetext{
Cite this article:

Flores-Bernedo, J., \& Vásquez-Castro, J. (2020). Susceptibility to Spirodiclofen in field populations of Tetranychus urticae (Acari: Tetranychidae) from strawberry plantations in Lima region, Peru. Peruvian Journal of Agronomy, 4(2), 61- 67. http://dx.doi.org/10.21704/pja.v4i2.1546
}

\footnotetext{
${ }^{1}$ Universidad Nacional Agraria La Molina, Faculty of Agronomy, Av. La Molina s/n, Lima 12, Peru..

${ }^{2}$ Universidad Nacional Agraria La Molina, Entomology Department, Faculty of Agronomy, Av. La Molina s/n, Lima 12, Peru.
} 


\section{Introduction}

Peru registers 2,000 ha of strawberry (Fragaria x ananassa Duch.); of these registers, approximately 1,200 is located in the Lima region, where the valleys of Chancay, Huaral, and Huaura stand out, with more than $50 \%$ of the national production area (Olivera, 2012). This crop is mainly cultivated by peasant farmers, with little technical and financial assistance (Redagrícola, 2017). The two-spotted spider mite (T. urticae) is a polyphagous pest that affects more than 1,000 vegetable species of 140 different families (Grbić et al., 2011) and is regarded as the most important pest of strawberry (González-Domínguez et al., 2015; Karlec et al., 2017), causing the death of the plant (Hoy, 2011).

The chemical method is an important measure for controlling T. urticae; therefore, most strawberry producers employ this method as the only strategy to control this pest (Bernardi et al., 2013; López et al., 2014). However, this strategy becomes less efficient as a result of the ease in which this pest develops resistance to chemical acaricides. This is explained by the mite's short life cycle, abundant progeny and arrhenotokous parthenogenesis, characteristics that favored the evolution of resistance, and reasons why this pest has become very difficult to control in many regions in the world (Bi et al., 2016; Van Leeuwen et al., 2010; Yalçin et al., 2018).

Spirodiclofen is a relatively new acaricide that is registered for mite control in a variety of crops. This molecule interferes with formation of fatty acids, acting on acetyl-CoA carboxylase enzyme (ACCase), a key enzyme in synthesis and metabolism of lipids (Cheng et al., 2013; Lümmen et al., 2014; Sparks \& Nauen, 2015). On the other hand, there are many reports of resistance of $T$. urticae to Spirodiclofen in literature (Demaeght et al., 2013; Farahani et al., 2018; Ferreira et al., 2015; Mohammadzadeh et al., 2014). However, in Peru, there are no scientific reports in this regard. Therefore, the study aimed to monitor the susceptibility to Spirodiclofen in field populations of $T$. urticae from strawberry plantations in north coast of Lima region, Peru.

\section{Materials and Methods}

\section{Characterization of susceptibility of T. urticae to Spirodiclofen}

The susceptible reference line was collected in acaliph plantation (Acalypha wilkesiana Müll. Arg.) at the Universidad Nacional Agraria La Molina (UNALM), Lima region, Peru. For identification of the specie, male mites were mounted on slide sheets and identified using dichotomous keys for Tetranychidae family of species (North American Plant Protection Organisation [NAPPO], 2014; Seeman \& Beard, 2011). The mites were transferred to UNALM Pesticide Toxicology Laboratory for breeding, according to the method proposed by Bustos et al. (2009). The formulation used for the bioassays was that of Spirosil ${ }^{\circledR}$ 250 SC (Spirodiclofen), which is registered for the control of T. urticae in strawberry (Fragaria x ananassa) (Servicio Nacional de Sanidad Agraria [SENASA], 2020).

The bioassay method described by Sato et al. (2005) was adopted with some modifications. Beans leaflets of approximately 30 days old were cut into a circular shape (50 $\mathrm{mm}$ diameter) and then individually conditioned with the underside facing up in a Petri dish $(90 \mathrm{~mm}$ diameter $\times 9 \mathrm{~mm}$ height) using a sponge moistened with distilled water. Strips of moistened paper towel were put over the edges of the leaf disc to act as a physical barrier to prevent mite leakage. Later, the leaves were sprayed with the acaricidal solution using an electric sprayer (National, Electric Sprayer MS-10 ${ }^{\circledR}$ ). Once the surface of the leaves was dry, 10 adult females (aged between 5 and 10 days) were placed on them and this was repeated five times. The bioassays were initially conducted with the susceptible reference line, using four doses equivalent to $20,10,1$, and $0.1 \%$ of the commercial product label dosage. This exploratory test was conducted to estimate the highest and lowest doses at which mortality rates of $99 \%$ and $1 \%$ are obtained, respectively (biological activity window). Afterward, we calculated seven logarithmic doses that would cover the mortality range. Then, the bioassay was conducted using 50 individuals for each dose and control, which was sprayed distilled water. The mites were kept in a bioclimatic chamber $\left(\mathrm{Climace} \mathrm{l}^{\circledR}\right.$ ) at $27^{\circ} \mathrm{C}, 65 \pm 5 \%$ of relative humidity and photoperiod of $14 \mathrm{~h}: 10 \mathrm{~h}$ light:dark cycle for $72 \mathrm{~h}$ (time at which mortality was evaluated), confirming death for individuals unable to move when stimulated by the touch of a brush. To obtain the $\mathrm{LC}_{50}$ and $\mathrm{LC}_{95}$, we applied the Probit analysis using the PoloSuite software (LeOra Software, 2016).

\section{Monitoring the resistance of T. urticae to Spirodiclofen}

Once the bioassays of the susceptible reference line were completed, we collected field populations from strawberry plantations of the San Andreas variety in four districts of the provinces of Huaral and Canta: Aucallama district

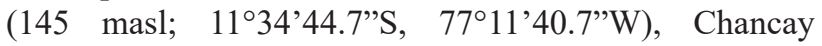
district (44 masl; 11 $\left.{ }^{\circ} 32^{\prime} 42.1^{\prime \prime} \mathrm{S}, 7^{\circ} 16^{\prime} 40.5^{\prime \prime} \mathrm{W}\right)$, Huaral

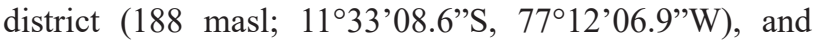

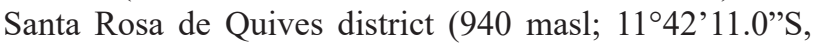
$\left.76^{\circ} 56^{\prime} 23.7^{\prime \prime} \mathrm{W}\right)$. The collected mites were transferred to the laboratory for breeding until production of F1, which was used for the bioassays. We used adult females aged between 5 and 10 days, which were exposed to $\mathrm{LC}_{50}$ and $\mathrm{LC}_{95}$ obtained for the susceptible reference line, using the same procedure described above. The experimental design was completely randomized with five repetitions. We subjected the mortality data obtained for each population to one-way analysis of variance and mean comparison by Tukey test at the significance level of $5 \%$. In additionally, we conducted interviews with the producers that own the 
strawberry plantations from which $T$. urticae populations were collected to better understand the results obtained.

\section{Results and Discussions}

\section{Characterization of T. urticae susceptibility to Spirodiclofen}

Table 1 shows the mortality percentage obtained from the exploratory test for four concentrations of the commercial product whose active ingredient is Spirodiclofen. This exploratory test aimed to find the minimum concentration that causes the lowest mortality above $0 \%$ and maximum concentration that causes the highest mortality below 100 $\%$. These concentrations represented $0.1,1,10$, and $20 \%$ of the label dosage equivalent to $0.0005,0.005,0.05$, and $0.1 \mathrm{~mL} . \mathrm{L}^{-1}$, respectively. The label dosage indicated in the fact sheet of Spirosil $250 \mathrm{SC}^{\circledR}$ for T. urticae control in strawberry plantations is $50 \mathrm{~mL} . \mathrm{hL}^{-1}$ or its $0.5 \mathrm{~mL} . \mathrm{L}^{-1}$ equivalent.

Table 1: Mortality of susceptible reference line treated with Spirodiclofen acaricide (bioassay to find biological window)

\begin{tabular}{cccc}
\hline Dosage $\left(\mathrm{mL} \cdot \mathrm{L}^{-1}\right)$ & $\begin{array}{c}\text { Number of } \\
\text { individuals }\end{array}$ & $\begin{array}{c}\text { Number of } \\
\text { deaths }\end{array}$ & $\begin{array}{c}\text { Mortality } \\
(\%)\end{array}$ \\
\hline Control & 50 & 2 & 4 \\
0.0005 & 50 & 6 & 12 \\
0.005 & 50 & 33 & 66 \\
0.05 & 50 & 42 & 84 \\
0.1 & 50 & 45 & 90 \\
\hline
\end{tabular}

Table 2: Mortality of susceptible reference line exposed to Spirodiclofen.

\begin{tabular}{cccc}
\hline Dosage $\left(\mathrm{mL} \cdot \mathrm{L}^{-1}\right)$ & $\begin{array}{c}\text { Number of } \\
\text { individuals }\end{array}$ & $\begin{array}{c}\text { Number of } \\
\text { deaths }\end{array}$ & $\begin{array}{c}\text { Mortality } \\
(\%)\end{array}$ \\
\hline Control & 50 & 1 & 2 \\
0.0005 & 50 & 5 & 10 \\
0.001 & 50 & 6 & 12 \\
0.003 & 50 & 16 & 32 \\
0.007 & 50 & 32 & 64 \\
0.02 & 50 & 40 & 80 \\
0.04 & 50 & 43 & 86 \\
0.1 & 50 & 46 & 92 \\
\hline
\end{tabular}

The chosen concentrations to be applied in characterization of susceptibility of $T$. urticae to Spirodiclofen were 0.0005 and 0.1 mL.L $\mathrm{L}^{-1}$, which yielded the mortality of $12 \%$ and $90 \%$, respectively. This allowed other equidistant concentrations to be calculated in a logarithmic scale in order to carry out the bioassay to estimate $\mathrm{LC}_{50}$ and $\mathrm{LC}_{95}$. The seven concentrations obtained for characterization of susceptibility of T. urticae to Spirodiclofen were $0.0005,0.001,0.003,0.007,0.02$, 0.04 , and $0.1 \mathrm{~mL} . \mathrm{L}^{-1}$. The mortality of $T$. urticae due to application of the aforementioned pesticide concentrations are presented in Table 2. The results obtained from Table 2 were subjected to Probit analysis using Polo Suite software (LeOra Software, 2016). Table 3 presents the Probit analysis results. The $\mathrm{LC}_{50}$ was $0.0056 \mathrm{~mL} . \mathrm{L}^{-1}$, while the $95 \%$ confidence interval was between 0.004 and 0.008 $\mathrm{mL} . \mathrm{L}^{-1}$, indicating that there is a $95 \%$ probability that the $\mathrm{LC}_{50}$ falls between both values, which are very close to the $\mathrm{LC}_{50}$ estimated by the Probit analysis. The $\mathrm{LC}_{95}$ was $0.1008 \mathrm{~mL} . \mathrm{L}^{-1}$, while the $95 \%$ confidence interval was between 0.057 and $0.227 \mathrm{~mL} . \mathrm{L}^{-1}$, indicating that there is a $95 \%$ probability that the $\mathrm{LC}_{95}$ falls between both values, which are more distant than the $\mathrm{LC}_{95}$ estimated by the Probit analysis. These results are common in toxicological experiments, where confidence intervals draw hyperbolic curves with respect to dose-mortality regression line, thus approaching $\mathrm{LC}_{50}$ and distancing at ends of the curve (for instance, $\mathrm{LC}_{10}$ or $\mathrm{LC}_{95}$ ).

The angular coefficient was 11.2, indicating that the doses used had a significant effect on mortality. When the angular coefficient of dose-mortality regression line is greater than 1.96, the regression is significant; therefore, our results are highly reliable. The calculated and tabulated Chi-square values $\left(\mathrm{X}^{2}\right)$ were of 4.0943 and 11.1, respectively, indicating that data from the experiment fits the Probit model satisfactorily. The heterogeneity, which results from dividing the calculated Chi-square by the degrees of freedom (5), resulted in a value of 0.8189 . In arthropod bioassays, it is recommended that the heterogeneity value does not exceed 4 (Robertson et al., 2017), as in the present study. The statistical results of the Probit analysis proved the suitability of the experimental method.

Figure 1 presents the dose/mortality regression curve of the Spirodiclofen-susceptible reference line of $T$.

Table 3: Probit analysis to characterize the basic line of susceptibility of T. urticae to Spirodiclofen.

\begin{tabular}{ccccccc}
\hline Population & $\begin{array}{c}\mathbf{L C}_{\mathbf{5 0}} \\
(\mathbf{C I} \text { 95\%) }\end{array}$ & $\begin{array}{c}\mathbf{L C}_{\mathbf{9 5}} \\
(\mathbf{C I} \text { 95\%) }\end{array}$ & $\begin{array}{c}\text { Angular coeffi- } \\
\text { cient } \pm \text { SE }\end{array}$ & $\mathrm{X}^{2}$ & d.f. & Heterogeneity \\
\hline \multirow{2}{*}{ Susceptible } & 0.0056 & 0.1008 & $11.2 \pm 0.12$ & 4.0943 & 5 & 0.8189 \\
& $(0.004-0.008)$ & $(0.057-0.227)$ & & & \\
\hline
\end{tabular}

$\mathrm{LC}_{50}$ : Mean lethal concentration (mL. $\left.\mathrm{L}^{-1}\right) ; \mathrm{LC}_{95}$ : Lethal concentration 95 (mL. $\left.\mathrm{L}^{-1}\right)$; CI 95\%: Confidence interval at $95 \%$; SE: Standard error of mean; $\mathrm{X}^{2}$ : Chi-square; d.f.: Degrees of freedom. 
urticae. It can be noted that a slight increase in the acaricide concentration can result in a significant mortality response. This curve shows the high sensitivity and efficiency of the bioassay method in assessment of susceptibility of $T$. urticae to Spirodiclofen.

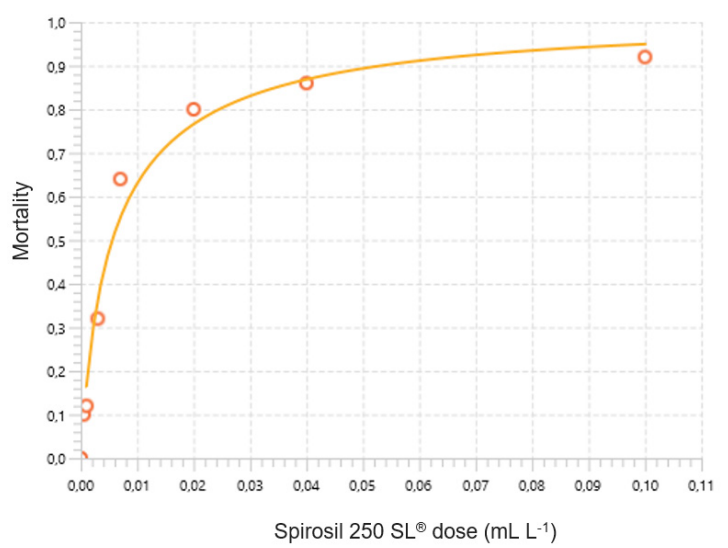

Figure 1. Dose/mortality regression curve of Spirodiclofen over the susceptible reference line T. urticae

Table 4: Mortality (\%) of four field populations of T. urticae due to LC50 of Spirodiclofen (0.0056 mL.L-1) obtained for the susceptible reference line.

\begin{tabular}{ccccc}
\hline Population & $\mathrm{n}$ & Mortality (\%) & Significance & S.E. \\
\hline Susceptible & 50 & 50 & $\mathrm{~A}$ & 1.32 \\
Huaral & 50 & 49 & $\mathrm{~A}$ & 1.32 \\
Aucallama & 50 & 49 & $\mathrm{~A}$ & 1.32 \\
Santa Rosa de & 50 & 48 & $\mathrm{~A}$ & 1.32 \\
Quives & & & $\mathrm{A}$ & 1.32 \\
Chancay & 50 & 46 & $\mathrm{~A}$ \\
\hline
\end{tabular}

Note: n: Number of adult females treated; Means comparison-Tukey test at $5 \%$ level of significance. Means with the same letter are not significantly different $(\mathrm{p}>0.05)$. S.E.: Standard error of mean.

Table 5: Mortality (\%) of four field populations of T. urticae due to LC95 of Spirodiclofen (0.1008 mL.L-1) obtained for the susceptible reference line.

\begin{tabular}{ccccc}
\hline Population & $\mathrm{n}$ & $\begin{array}{c}\text { Mortality } \\
(\%)\end{array}$ & Significance & S.E. \\
\hline Susceptible & 50 & 95 & $\mathrm{~A}$ & 1.83 \\
Huaral & 50 & 97 & $\mathrm{~A}$ & 1.83 \\
Aucallama & 50 & 97 & $\mathrm{~A}$ & 1.83 \\
Santa Rosa de & 50 & 96 & $\mathrm{~A}$ & 1.83 \\
Quives & & 94 & $\mathrm{~A}$ & 1.83 \\
Chancay & 50 & 94
\end{tabular}

Note: $\mathrm{n}$ : Number of adult females treated; Means comparison -Tukey test at $5 \%$ level of significance. Means with the same letter are not significantly different $(\mathrm{p}>0.05)$. S.E.: Standard error of mean.

\section{Monitoring of T. urticae resistance to Spirodiclofen}

The results of mortality and mean comparison by Tukey test $(\alpha=0.05)$ are presented in Table 4 and 5. The $\mathrm{LC}_{50}$ and $\mathrm{LC}_{95}$ of the susceptible reference line caused the same mortality in all the studied populations; That is, the populations of T. urticae from Aucallama, Chancay, Huaral, and Santa Rosa de Quives were susceptible to Spirodiclofen.

These results confirm the susceptibility of the four studied populations to Spirodiclofen. However, it is important to consider the interviews with the strawberry producers of the four localities, which are essential to understand the factors that influenced the susceptibility of the pest to Spirodiclofen.

\section{Huaral population}

The determining factor in this locality was crop management. For several years, the producer has been running a product rotation program with different modes of action. In June-November 2019 season, the producer applied 10 pesticides for the control of T. urticae in the following sequence: Bifenazate, Spirodiclofen, Abamectin, Etoxazole, Cyflumetofen, Abamectin, Etoxazole, Bifenazate, Abamectin, and Spiromesifen. The producer avoided the sequential use of two active ingredients that possess the same mode of action. Marčić (2012) presumed that delay of resistance includes actions such as rotation and mixing of compounds of different modes of action. Rotation between products of different modes of action is a necessary strategy for management of resistance and the producer in this locality is clearly aware of this.

\section{Aucallama population}

The factor that influenced the preservation of susceptibility of T. urticae to Spirodiclofen was that the producer was unaware of the existence of this acaricide under any trade name, despite the fact that different formulations that contain the active ingredient are sold in pesticide stores in the locality. The strategy for control of $T$. urticae used by the producer in Aucallama was the exclusive use of Abamectin, without rotation with other molecules.

\section{Chancay population}

The factor that influenced the susceptibility of T. urticae to Spirodiclofen in the Chancay valley was the commercial destination of the strawberry, in which USA and Japan are the main market. For Japan, Maximum Residue Limit (MRL) is $2 \mathrm{mg} \cdot \mathrm{kg}^{-1}$; however, the same does not apply for USA. In the latter country, Spirodiclofen does not have an MRL for strawberry crops; therefore, it cannot be used. As Chancay production is indistinctly shipped to Japan and USA, the exporting companies in the area have decided not to use Spirodiclofen in their plantations. The companies (Arcor de Perú S.A., Gofresh S.A.C, and Agro Laure S.A.C) are in charge of collecting and exporting strawberry from Chancay valley, demanding the farmers' compliance to a series of regulations, among which is the use of authorized pesticides in target market. In this way, the use of Spirodiclofen is not allowed for the farmers that supply strawberries to exporting companies. Therefore, the population of T. urticae remains susceptible 
to Spirodiclofen due to absence of selective pressure by this acaricide. However, other active ingredients (such as Abamectin, Etoxazole, Bifenazate, and Spiromesifen) are used. Notably, Spiromesifen has the same mode of action as Spirodiclofen.

\section{Santa Rosa de Quives Population}

In this locality, the producer was unaware of any commercial product that contains Spirodiclofen. On the other hand, the pesticide stores in Santa Rosa de Quives do not sell any formulation containing Spirodiclofen. The most widely used acaricide for control of T. urticae in this locality is Abamectin. The producer indicated that he had used Spiromesifen a few times.

In Huaral, Chancay and Santa Rosa de Quives, Spiromesifen (which has the same mode of action as Spirodiclofen) is used. Apparently, there is no cross resistance between these two acaricides, despite having the same mode of action (Ferreira et al., 2015). The mechanism of resistance to Spirodiclofen provides only low to no cross-resistance to Spiromesifen (Kramer \& Nauen, 2011). Therefore, the multiple use of the three commercially available lipid biosynthesis inhibitors (IRAC group 23) is recommended (Elbert et al., 2008). This may partially explain the high susceptibility of $T$. urticae to Spirodiclofen in the studied valleys.

Spirodiclofen is a useful tool for control of T. urticae in strawberry plantations in Huaral, Aucallama, Chancay, and Santa Rosa de Quives valleys and, therefore, its inclusion in the acaricide rotation program for the control of mites is recommended. However, given that Spirodiclofen is a contact acaricide (Nauen et al., 2003) and that T. urticae resides mainly on the underside of leaves (Renkena et al., 2020), it is important to improve the application method to achieve an adequate coverage for effective pest control, with the least possible environmental contamination.

\section{Conclusion}

Populations of T. urticae from strawberry plantations of the provinces of Aucallama, Chancay, Huaral, and Santa Rosa de Quives are highly susceptible to Spirodiclofen.

The sporadic use of this molecule by farmers and the apparent no cross-resistance between Spirodiclofen and Spiromesifen have contributed to maintaining the susceptibility of the populations studied. Thus, Spirodiclofen is a useful tool in T. urticae control programs in strawberry cultivation in the Lima region.

\section{References}

Bernardi, D., Botton, M., Silva, U., Bernardi, O., Malausa, T., Garcia, M., \& Nava, D. (2013). Effects of azadirachtin on Tetranychus urticae (Acari: Tetranychidae) and its compatibility with predatory mites (Acari: Phytoseiidae) on strawberry. Pest Management, 69(1), 75-80. https://doi.org/10.1002/ ps.3364

Bi, J.L., Niu, Z.M., Yu, L., \& Toscano, N.C. (2016). Resistance status of the carmine spider mite, Tetranychus cinnabarinus and the twospotted spider mite, Tetranychus urticae to selected acaricides on strawberries. Insect Science, 23(1), 88-93. https://doi. org/10.1111/1744-7917.12190

Bustos, A., Cantor, F., Cure, J.R., \& Rodríguez, D. (2009). Padronização da criação de Tetranychus urticae Koch (Acari: Tetranychidae) em feijoeiro (Phaseolus vulgaris): idade da planta e tempo de colheita. Neotropical Entomology, 38(5), 653-659. https://doi. org/10.1590/S1519-566X2009000500015

Cheng, J., He, X., Wang, Z., Zhang, J., Zhao, J., \& Zhu, G. (2013). Metabolism-based synthesis, biological evaluation and structure-activity relationship analysis of spirotetramat analogues as potential lipid biosynthesis inhibitors. Pest Management Science, 69(10), 1121-1130. https://doi.org/10.1002/ps.3473

Demaeght, P., Dermauw, W., Tsakireli, D., Khajehali, J., Nauen, R., Tirry, L., Vontas, J., Lümmen, P., \& Van Leeuwen, T. (2013). Molecular analysis of resistance to acaricidal spirocyclic tetronic acids in Tetranychus urticae: CYP392E10 metabolizes Spirodiclofen, but not its corresponding enol. Insect Biochemistry and Molecular Biology, 43(6), 544-554. https://doi. org/10.1016/j.ibmb.2013.03.007

Elbert, A., Nauen, R. \& Salmon, E. (2008). Resistance management guidelines for the new ketoenol insecticide Movento ${ }^{\circledR}$. Bayer CropScience Journal, 61, 403-418.

Farahani, S., Bandani, A., \& Eslami, S. (2018). Comparison of susceptibility of two Iranian populations of Tetranychus urticae Koch (Acari: Tetranychidae) to Spirodiclofen. Persian Journal of Acarology, 7(3), 279-287. http://dx.doi.org/10.22073/ pja.v7i3.36682

Ferreira, C.B.S., Andrade, F.H.N., Rodrigues, A.R.S., Siqueira, H.A.A., \& Gondim, M.G.C. (2015). Resistance in field populations of Tetranychus urticae to acaricides and characterization of the inheritance of abamectin resistance. Crop Protection, 67(1), 77-83. https://doi.org/10.1016/j.cropro.2014.09.022

González-Domínguez, S., Santillán-Galicia, M., González-Hernández, V., Suárez, J., \& GonzálezHernández, H. (2015). Variability in damage caused by the mite Tetranychus urticae (Trombidiformes: 
Tetranychidae) Koch on three varieties of strawberry. Journal of Economic Entomology, 108(3), 1371-1380. https://doi.org/10.1093/jee/tov084

Grbić, M., Van Leeuwen, T., Clark, R. M., Rombauts, S., Rouzé, P., Grbíc, V., Osborne, E. J., Dermauw, W., Thi Ngoc, P. C., Ortego, F., Hernández-Crespo, P., Díaz, I., Martínez, M., Navajas, M., Sucena, E., Magalhñes, S., Nagy, L., Pace, R. M., Djuranovic, S.,... Van de Peer, Y. (2011). The genome of Tetranychus urticae reveals herbivorous pest adaptations. Nature, 479, 487-492. https://doi.org/10.1038/nature10640

Hoy, M. (2011). Agricultural Acarology: Introduction to Integrated Mite Management. Boca Ratón, USA, CRC Press. https://doi.org/10.1201/b10909

Karlec, F., Da Fonseca, A., De Oliveira, A., \& Da Cunha, U. (2017). Development of Tetranychus urticae Koch (Acari: Tetranychidae) in different strawberry cultivars. Revista Brasileira de Fruticultura, 39(1), 1-8. https://doi.org/10.1590/0100-29452017171

Kramer, T. \& Nauen, R. (2011). Monitoring of spirodiclofen susceptibility in field populations of European red mites, Panonychus ulmi (Koch) (Acari: Tetranychidae), and the cross-resistance pattern of a laboratory-selected strain. Pest Management Science, 67(10), 1285-1293. https://doi.org/10.1002/ps.2184

LeOra Software. (2016). POLOSUITE. A user's guide to probit or logit analysis.

López, L., Guzmán-Ortíz, D., García, J., Chávez, C., \& Peña-Cabriales, J. (2014). Consideraciones para mejorar la competitividad de la región "El Bajío" en la producción nacional de fresa. Revista Mexicana de Ciencias Agrícolas, 5(4), 673-686. https://doi. org/10.29312/remexca.v5i4.929

Lümmen, P., Khajehali, J., Luther, K., \& Van Leeuwen, T. (2014). The cyclic keto-enol insecticide spirotetramat inhibits insect and spider mite Acetyl-CoA carboxylases by interfering with the carboxyltransferase partial reaction. Insect Biochemistry and Molecular Biology, 55, 1-8. https://doi.org/10.1016/j.ibmb.2014.09.010

Marčić, D. (2012). Acaricides in modern management of plant feeding mites. Journal of Pest Science, 85(4), 395-408. https://doi.org/10.1007/s10340-012-04421

Mohammadzadeh, M., Bandani, A.R., \& Sabahi, Q. (2014). Comparison of susceptibility of two populations of Tetranychus urticae Koch to two acaricides, Abamectin and Propargite. Archives of Phytopathology and Plant Protection, 47(17), 2112-2123. https://doi.org/10.108 $0 / 03235408.2013 .869890$

North American Plant Protection Organization (2014). Morphological identification of spider mites (Tetranychidae) affecting imported fruits. Ottawa, Canada, 34p. https://nappo.org/application/ files/3515/8322/7229/DP 03 Tetranychidae-e.pdf

Nauen, R., Bretschneider, T., Elbert, R., Fischer, R., \& Tieman, R. (2003). Spirodiclofen and Spiromesifen. Pesticide Outlook, 14, 243-246. https://doi. org/10.1039/B314855F

Olivera, J. (2012). Cultivo de Fresa (Fragaria x ananassa Duch.). Lima, Perú. https://repositorio.inia.gob.pe/ handle/inia/752

Redagrícola. (2017). La hora de las fresas (on line). http:// www.redagricola.com/pe/la-hora-las-fresas/

Renkena, J., Dubon, F., Peres, N., \& Evans, B. (2020). Twospotted spider mites (Tetranychus urticae) on strawberry (Fragaria $\times$ ananassa) transplants, and the potential to eliminate them with steam treatment. International Journal of Fruit Science. https://doi.org/ 10.1080/15538362.2020.1755769

Robertson, J., Jones, M., Olguin, E., \& Alberts, B. (2017). Bioassays with Arthropods. California, United States, CRC press. https://doi.org/10.1201/9781315373775

Sato, M.E., da Silva, M.Z., Raga, A., \& de Souza Filho, M.F. (2005). Abamectin resistance in Tetranychus urticae Koch (Acari: Tetranychidae): Selection, crossresistance and stability of resistance. Neotropical Entomology, 34(6), 991-998. https://doi.org/10.1590/ S1519-566X2005000600016

Seeman, O., \& Beard, J. (2011). Identification of exotic pest and Australian native and naturalized species of Tetranychus (Acari: Tetranychidae). Zootaxa, 296, 1-72. https://doi.org/10.11646/zootaxa.2961.1.1

Servicio Nacional de Sanidad Agraria. (2020). Sistema Integrado de Gestión de Insumos Agropecuarios (SIGIA): Consulta del Registro de plaguicidas (on line). https://servicios.senasa.gob.pe/SIGIAWeb/ sigia_consulta_plaga.html

Sparks, T., \& Nauen, R. (2015). IRAC: Mode of action classification and insecticide resistance management. Pesticide Biochemistry and Physiology, 121, 122-128. https://doi.org/10.1016/j.pestbp.2014.11.014

Van Leeuwen, T., Vontas, J., Tsagkarakou, A., Dermauw, W., \& Tirry, L. (2010). Acaricide resistance mechanisms in the two-spotted spider mite Tetranychus urticae and other important Acari: A review. Insect Biochemistry and Molecular Biology, 40(8), 563-572. https://doi. org/10.1016/j.ibmb.2010.05.008

Yalçin, K., Döker I., \& Kazak C. (2018). Acaricide resistance in Tetranychus urticae red form (Acari: Tetranychidae) collected from strawberry in southern 
Turkey: Bioassay and biochemical studies. Systematic and Applied Acarology, 23(12), 2279-2287. https:// doi.org/10.11158/saa.23.12.1 